\title{
HUBUNGAN ANTARA KADAR LIPID DARAH DENGAN DERAJAT HERNIASI DISKUS INTERVERTEBRALIS
}

\author{
THE CORRELATION BETWEEN SERUM LIPID LEVELS WITH THE SEVERITY \\ OF INTER-VERTEBRAL DISC HERNIATION
}

Elsa Ana Purika, * Susi Aulina, * Audry Devisanty Wuysang, * Andi Alfian Zainuddin**

\section{ABSTRACT}

Introduction: Inter-vertebral Disc Herniation (IDH) is one of the common causes of low back pain (LBP). High level of blood lipids is a risk factor for atherosclerosis, and responsible as the cause of decreased blood supply to the intervertebral discs which basically has minimal vascularization, thus, it is estimated that there is a relationship between blood lipid levels and IDH.

Aim: To identify the correlation between serum lipid levels with the severity of IDH.

Methods: Clinical trials with cross sectional designs were carried out on subjects with IDH during April to June 2018 in Dr. Wahidin Sudirohusodo Hospital, Makassar. Serum lipid levels (HDL, LDL, triglyceride and total cholesterol) were examined and the degree of disc herniation (1 to 4) was assessed. Data analyzed using the Spearman correlation test.

Results: In this study there were 40 subjects, 15 males and 25 females, with mean age 50.75 (30-62) years old. Most patients were found with degrees of IDH 2 and 3 (total 75\%). The Spearman correlation test showed that there was a negative correlation between $H D L$ with degrees of $I D H$, as well as a positive correlation between $L D L$ and triglycerides with degrees of IDH, but there was no correlation between total cholesterol levels with degrees of IDH.

Discussion: The lower the HDL level, the higher the degree of IDH. On the other hand, the higher the level of LDL and triglycerides, the higher the degree of IDH.

Keywords: Inter-vertebral disc herniation, low back pain, serum lipid levels

\section{ABSTRAK}

Pendahuluan: Herniasi diskus intervertebralis (HDI) merupakan salah satu penyebab nyeri punggung bawah (LBP) yang cukup sering terjadi. Tingginya kadar lipid darah merupakan faktor risiko untuk aterosklerosis, dan bertanggung jawab sebagai penyebab menurunnya suplai darah pada diskus intervertebralis yang pada dasarnya sudah minim vaskularisasi, sehingga diperkirakan terdapat hubungan antara kadar lipid darah dengan penyakit degenerasi diskus intervertebralis.

Tujuan: Mengetahui hubungan antara kadar lipid darah dengan derajat herniasi diskus intervertebralis.

Metode: Penelitian potong lintang terhadap subjek dengan herniasi diskus intervertebralis yang berobat ke RSUP Dr. Wahidin Sudirohusodo, Makassar, selama bulan April-Juni 2018. Dilakukan penilaian kadar lipid darah (HDL, LDL, trigiliserida, dan kolesterol total) serta derajat herniasi diskus intervertebralis (1 sampai 4) berdasarkan gejala klinis dan gambaran MRI. Analisis data menggunakan uji korelasi Spearman.

Hasil: Didapatkan 40 subjek yang terdiri atas 15 orang laki-laki dan 25 orang perempuan dengan rerata usia 50,75 (30-62) tahun. Mayoritas subjek mengalami HDI derajat 2 dan 3 (total 75\%). Uji korelasi Spearman menunjukkan adanya korelasi negatif antara kadar HDL dengan derajat HDI, serta korelasi positif antara kadar LDL dan trigliserida dengan derajat HDI, namun tidak terdapat korelasi antara kadar kolesterol total dengan derajat HDI.

Diskusi: Semakin rendah kadar HDL, maka semakin berat derajat HDI. Sebaliknya semakin tinggi kadar LDL dan trigliserida, maka semakin berat derajat HDI.

Kata kunci: Herniasi diskus intervertebralis, kadar lipid darah, nyeri punggung bawah

*Departemen Neurologi FK Universitas Hasanuddin, Makassar; **Departemen Ilmu Kesehatan Masyarakat, FK Universitas Hasanuddin, Makassar. Korespondensi: elsa.anapurika@gmail.com.

\section{PENDAHULUAN}

Nyeri punggung bawah (NPB) merupakan keluhan yang sangat lazim terjadi, sekitar $12-33 \%$ di negara berkembang. Di Indonesia, NPB lebih sering dijumpai pada golongan usia sekitar 40 tahun dengan penyebab tersering hernia nukleus pulposus atau herniasi diskus intervertebralis (HDI), yaitu 19,6\% pada usia 20-60 tahun. ${ }^{1}$
Herniasi diskus intervertebralis merupakan suatu keadaan ruptur annulus fibrosus, sehingga nukleus pulposus melejit (herniasi) keluar dan menekan saraf di dekatnya. Umumnya herniasi terjadi pada lumbal, antara L4-L5 dan L5-S1, yang melibatkan radiks L4, L5, dan S1. Hal ini disebabkan penekanan hampir selalu terjadi ke arah posterior atau posterolateral tempat keluarnya radiks, karena 
ligamentum longitudinalis anterior lebih kuat dibandingkan ligamentum longitudinalis posterior. ${ }^{2}$

Sejauh ini mekanisme patofisiologi penyebab HDI masih belum jelas. Longo dkk dan Heuch dkk menyatakan adanya hubungan antara kadar lipid darah dengan penyakit degeneratif diskus intervertebralis. ${ }^{3-4}$ Kadar lipid darah yang abnormal merupakan faktor risiko terjadinya aterosklerosis. Demikian pula peningkatan kadar kolesterol low density lipoprotein (LDL) berhubungan dengan degenerasi diskus pada fase awal. ${ }^{5}$ Sebuah studi menyatakan bahwa pasien dengan HDI simtomatik memiliki kadar trigliserida dan kolesterol total yang tinggi. ${ }^{5}$

Studi otopsi 86 laki-laki menyimpulkan bahwa aterosklerosis pada aorta abdominal dan khususnya stenosis pada arteri segmental vertebralis berperan potensial terhadap degenerasi diskus intervertebralis. ${ }^{6}$ Suplai darah yang tidak mencukupi akibat aterosklerosis dipercaya sebagai faktor penyebab degenerasi diskus intervertebralis yang terkait dengan kejadian HDI. ${ }^{3}$

Tingginya kadar lipid darah merupakan faktor risiko untuk aterosklerosis, dan bertanggung jawab sebagai penyebab menurunnya suplai darah pada diskus intervertebralis yang pada dasarnya sudah minim vaskularisasi. Pada tingkat jaringan, struktur dengan pasokan nutrisi yang sulit, seperti diskus intervertebralis, secara bertahap dapat mengalami degenerasi sebagai akibat dari kegagalan pasokan nutrisi pada diskus intervertebralis. ${ }^{3}$ Sejauh ini hubungan antara kadar lipid, sebagai salah satu faktor aterosklerosis, dengan HDI di Indonesia sangat terbatas dan belum pernah dipublikasikan sebelumnya.

\section{TUJUAN}

Untuk mengetahui hubungan antara kadar lipid darah dengan derajat herniasi diskus intervertebralis.

\section{METODE}

Penelitian potong lintang terhadap penderita herniasi diskus intervertebralis yang berobat di RSUP Dr. Wahidin Sudirohusodo, Makassar, secara konsekutif pada bulan April hingga Juni 2018. Kriteria inklusi adalah pasien berusia 18-65 tahun yang bersedia menjadi subjek penelitian. Kriteria eksklusi meliputi pasien dengan indeks massa tubuh (IMT) $\geq 30$, merokok, adanya diabetes mellitus dan/ atau hipertensi, dalam terapi dislipidemia, riwayat trauma tulang belakang, dan pasien dengan aktivitas berat.

Herniasi diskus intervertebralis merupakan berpindahnya nukleus pulposus dari tempatnya (herniasi) karena robeknya annulus fibrosus dengan gejala nyeri punggung bawah yang dapat atau tidak menjalar ke tungkai. Diagnosis ini ditegakkan berdasarkan anamnesis, pemeriksaan fisik, dan MRI tulang belakang.

Derajat HDI dinilai berdasarkan gejala klinis dan MRI tulang belakang, yaitu derajat 1 (bulging): nukleus menonjol tanpa kerusakan annulus fibrosus dan muncul gejala NPB lokal; derajat 2 (protrusio): nukleus berpindah tapi masih dalam lingkaran annulus fibrosus dan muncul iskialgia; derajat 3 (extrusio): nukleus keluar dari annulus fibrosus dan berada dibawah ligamentum longitudinalis posterior, muncul atrofi otot, serta hilangnya refleks tendon patella dan Achilles; serta derajat 4 (sekuestrasi): nukleus telah menembus ligamentum longitudinalis posterior, muncul gejala paraplegi, dan atrofi otot bertambah berat.

Kadar lipid darah adalah kadar lemak yang terdapat di dalam tubuh manusia yang terdiri dari kolesterol total, trigliserida, high density lipoprotein (HDL), dan LDL yang didapat melalui pemeriksaan laboratorium darah setelah berpuasa selama 10-12 jam. Kadar normal lipid darah adalah kolesterol total $<200 \mathrm{mg} / \mathrm{dL}$, trigliserida $<150 \mathrm{mg} / \mathrm{dL}, \mathrm{HDL}>60 \mathrm{mg} /$ dL, dan LDL $<100 \mathrm{mg} / \mathrm{dL}$.

Penilaian IMT berdasarkan Pedoman Praktis Terapi Gizi Medis Departemen Kesehatan RI (2003), yaitu berat badan (BB) kg/tinggi badan (TB) ${ }^{2}$ (dalam meter), dengan nilai normal untuk perempuan adalah $17-23 \mathrm{~kg} / \mathrm{m}^{2}$ dan laki-laki $18-25 \mathrm{~kg} / \mathrm{m}^{2}$.

Penelitian ini telah mendapat persetujuan etik oleh komisi etik penelitian Kementerian Riset, Teknologi, dan Pendidikan Tinggi Universitas Hasanuddin. Analisis data menggunakan program SPSS versi 22. Untuk menilai hubungan antar 
variabel dilakukan uji korelasi Spearman dengan nilai $\mathrm{p}<0,05$ dianggap bermakna.

\section{HASIL}

Terdapat 40 subjek pada penelitian ini yang terdiri dari 15 laki-laki dan 25 perempuan. Rerata usia subjek adalah 50,75 (30-62) tahun dan rerata IMT dalam batas normal, yaitu 23,44 $(17,7-28,4) \mathrm{kg} / \mathrm{m}^{2}$. Adapun rerata kadar lipid subjek tidak normal, yaitu rendahnya kadar HDL, serta tingginya kadar LDL, trigliserida, dan kolesterol total (Tabel 1). Derajat HDI paling banyak adalah derajat 2 (protrusio) dan 3 (ekstrusio), sejumlah 75\% (Tabel 2).

Tabel 1. Karakteristik Data Penelitian $(n=40)$

\begin{tabular}{lcc}
\hline \multicolumn{1}{c}{ Variabel } & Rerata & SD \\
\hline Umur & $50,75(30-62)$ & 7,14 \\
IMT & $23,44(17,7-28,4)$ & 2,25 \\
HDL & $48,30(18-97)$ & 16,32 \\
LDL & $137,15(66-236)$ & 37,07 \\
Trigliserida & $159,50(68-434)$ & 90,36 \\
Kolesterol Total & $215,73(121-381)$ & 55,73 \\
\hline
\end{tabular}

Data primer 2018; SD: standar deviasi; IMT: indeks massa tubuh; HDL: high-density lipoprotein; LDL: low-density lipoprotein.

Tabel 2. Karakteristik Derajat HDI $(n=40)$

\begin{tabular}{|c|c|}
\hline Derajat HDI & n $(\%)$ \\
\hline Derajat 1 & $5(12,5)$ \\
\hline Derajat 2 & $17(42,5)$ \\
\hline Derajat 3 & $13(32,5)$ \\
\hline Derajat 4 & $5(12,5)$ \\
\hline
\end{tabular}

HDI: Herniasi diskus intervertebralis.

Uji korelasi Spearman menunjukkan korelasi antara derajat HDI dengan HDL $(p=0,04)$ dengan kekuatan korelasi negatif lemah $(\mathrm{r}=-0,327)$. Dapat disimpulkan semakin rendah kadar HDL, maka semakin berat derajat HDI (Tabel 3). Demikian pula terdapat korelasi antara derajat HDI dengan LDL $(\mathrm{p}=0,015)$ dan memiliki kekuatan korelasi positif lemah $(\mathrm{r}=0,380)$ yang berarti semakin tinggi kadar LDL, maka semakin berat derajat HDI.

Tabel 4 menunjukkan adanya korelasi antara derajat HDI dengan kadar trigliserida $(\mathrm{p}=0,003)$ dan memiliki kekuatan korelasi positif sedang $(\mathrm{r}=0,455)$, yang berarti semakin tinggi kadar trigliserida maka semakin berat derajat HDI.

\section{PEMBAHASAN}

Penelitian ini mendapatkan rerata usia subjek

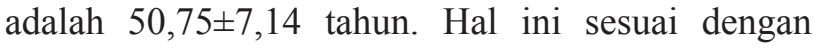
Roger dkk bahwa usia yang paling sering mengalami HDI adalah 35-60 tahun, ${ }^{7}$ seiring bertambahnya usia annulus fibrosus akan kehilangan elastisitasnya, sehingga mudah berubah bentuk dan ruptur. Kadar mukopolisakarida berkurang, terjadi peningkatan kondroitin sulfat, maka viskositas dan kapasitas untuk berikatan dengan air pada proteoglikan berkurang sehingga menyebabkan diskus intervertebralis mudah berubah bentuk.

Pada penelitian ini didapatkan korelasi negatif lemah antara derajat HDI dan HDL, yaitu semakin rendah kadar HDL maka semakin berat derajat HDI. Hal ini sesuai dengan penelitian Heuch dkk yang menyatakan bahwa kadar HDL yang abnormal dianggap sebagai faktor risiko independen yang ditetapkan untuk aterosklerosis dan HDL berhubungan dengan NPB kronik. ${ }^{5}$

Pada penelitian ini juga didapatkan korelasi positif lemah antara derajat HDI dengan LDL, semakin tinggi nilai LDL maka semakin berat pula derajat HDI. Penelitian ini sesuai dengan Zhang dkk yang menyatakan bahwa semakin tinggi kadar LDL, maka akan semakin besar kemungkinan kejadian

Tabel 3. Korelasi antara Derajat HDI dengan kadar HDL dan LDL $(n=40)$

\begin{tabular}{|c|c|c|c|c|c|c|c|c|}
\hline \multirow{2}{*}{$\begin{array}{c}\text { Derajat } \\
\text { HDI }\end{array}$} & \multicolumn{4}{|c|}{ HDL } & \multicolumn{4}{|c|}{ LDL } \\
\hline & Rerata & SD & $\mathbf{r}$ & p* & Mean & SD & $\mathbf{r}$ & $\mathbf{p}^{*}$ \\
\hline Derajat 1 & $\begin{array}{c}50,00 \\
(45-57)\end{array}$ & 4,89 & & & $106,20(70-138)$ & 28,75 & 0,380 & 0,015 \\
\hline Derajat 2 & $\begin{array}{c}51,88 \\
(28-96)\end{array}$ & 15,78 & 0227 & $0 \Omega 4$ & $131,06(66-175)$ & 31,40 & & \\
\hline Derajat 3 & $\begin{array}{c}49,69 \\
(29-97)\end{array}$ & 18,14 & $-0,3<1$ & 0,04 & $151,92(84-236)$ & 41,36 & & \\
\hline Derajat 4 & $\begin{array}{c}30,80 \\
(18-48)\end{array}$ & 11,99 & & & $150,40(100-186)$ & 34,82 & & \\
\hline
\end{tabular}

Uji Spearman; HDL: high-density lipoprotein; LDL: low-density lipoprotein; SD: standar deviasi; HDI: herniasi diskus intervertebralis. 
Tabel 4. Korelasi antara Derajat HDI dengan Trigliserida dan Kolesterol Total $(n=40)$

\begin{tabular}{|c|c|c|c|c|c|c|c|c|}
\hline \multirow{2}{*}{$\begin{array}{c}\text { Derajat } \\
\text { HDI }\end{array}$} & \multicolumn{4}{|c|}{ Trigliserida } & \multicolumn{4}{|c|}{ Kolesterol Total } \\
\hline & Rerata & SD & $\mathbf{r}$ & $\mathbf{p}$ & Rerata & SD & $\mathbf{r}$ & $\mathbf{p}$ \\
\hline Derajat 1 & $\begin{array}{c}110,40 \\
(68-148)\end{array}$ & 29,98 & & & $\begin{array}{c}174,40 \\
(134-213)\end{array}$ & 31,01 & 0,255 & 0,112 \\
\hline Derajat 2 & $\begin{array}{c}137,41 \\
(72-399)\end{array}$ & 75,37 & & & $\begin{array}{c}211,24 \\
(128-283)\end{array}$ & 51,49 & & \\
\hline Derajat 3 & $\begin{array}{c}187,31 \\
(83-434)\end{array}$ & 121,24 & 0,455 & 0,003 & $\begin{array}{c}239,23 \\
(121-381)\end{array}$ & 69,14 & & \\
\hline Derajat 4 & $\begin{array}{c}211,40 \\
(186-259)\end{array}$ & 28,90 & & & $\begin{array}{c}211,20 \\
(183-231)\end{array}$ & 18,19 & & \\
\hline
\end{tabular}

Uji Spearman; SD: standar deviasi; HDI: herniasi diskus intervertebralis.

HDI. ${ }^{5}$ Tingginya kadar kolesterol LDL merupakan faktor risiko terjadinya aterosklerosis pada arteri lumbalis, yang bertanggung jawab sebagai penyebab menurunnya suplai darah pada diskus intervertebralis yang sudah minim vaskularisasi. Hal ini berhubungan dengan proses aterogenesis bahwa bila terjadi kerusakan endotel pembuluh darah, maka LDL akan menginduksi terbentuknya sitokin lokal yang menyebabkan migrasi langsung monosit ke dinding intima, sehingga terjadilah plak aterosklerosis dan kalsifikasi. ${ }^{8}$

Dari penelitian ini ditemukan korelasi antara derajat HDI dengan trigliserida, semakin tinggi nilai trigliserida, maka semakin berat derajat HD. Hasil tersebut sesuai dengan Longo dkk bahwa peningkatan kadar trigliserida dapat menjadi faktor risiko terjadinya herniasi diskus intervertebralis. ${ }^{3}$ Tingginya kadar trigliserida merupakan faktor risiko terjadinya aterosklerosis pada arteri lumbalis, sehingga akan mendestruksi suplai darah pada diskus intervertebralis yang sudah minim vaskularisasi. ${ }^{5}$

Pada penelitian ini tidak didapatkan korelasi antara derajat HDI dan kadar kolesterol total. Hal ini sesuai dengan Heuch dkk yang menyatakan bahwa tidak terdapat hubungan yang pasti antara risiko LBP kronik dengan kadar kolesterol total. ${ }^{5}$

Penelitian ini merupakan penelitian pertama di Indonesia yang mengungkapkan hubungan antara kadar lipid darah dengan derajat HDI. Namun terdapat keterbatasan tidak dilakukannya pemeriksaan angiografi pada arteri lumbalis untuk memastikan lokasi oklusi pembuluh darah arteri lumbalis pada sampel dan dan peneliti tidak mencari korelasi antara temuan radiologi dengan klinis neurologi.

\section{KESIMPULAN}

Terdapat korelasi antara profil lipid dengan HDI. Sebagaimana halnya faktor risiko aterosklerosis, LDL dan trigliserida berkorelasi positif dengan derajat HDI, sedangkan HDL berkorelasi negatif terhadap HDI.

\section{DAFTAR PUSTAKA}

1. Rodrigo D, Gastal A, Muller N. Prevalence of chronic low back pain: systematic review. Rev Saude Publica. 2015;49(7):1.

2. Mardjono M, Sidharta P. Neurologi klinis dasar. Jakarta: Dian Rakyat, 2012. h. 93-4.

3. Longo U, Denaro L, Spiezia F, Forriol F, Maffulli N, Denaro V. Symptomatic disc herniation and serum lipid levels. Eur Spine. 2011;20(10):1658-62.

4. Heuch I, Hagen K, Zwart J. Do abnormal serum lipid levels increase the risk of chronic low back pain? The Nord-Trondelag Health Study. PLoS One. 2014;9(9):e108227.

5. Zhang Y, Zhao Y, Wang M, Si M, Li J, Hou Y, dkk. Serum lipid levels are positively correlated with lumbar disc herniation-restrospective study of 790 chinese patient. Lipids Health Dis. 2016;15:80.

6. Leino P, Kaila-Kangas L, Solovieva S, Riihimaki H, Kirjonen J, Reunanen A. Serum lipid and low back pain: an association? A follow-up study of a working population sample. Spine (Phila $\mathrm{Pa} 1976$ ). 2006;31(9):1032-7.

7. Roger H. Lumbar herniated disc: causes and risk factors. Spine-Health [serial online]. 2016 [diunduh 18 Februari 2018]. Tersedia dari: Spine.

8. Lilly, Leonard S. Handbook of pathophysiology of heart disease. Edisi ke-5. Philadelphia: Lippincott Williams \& Wilkins; 2011. 